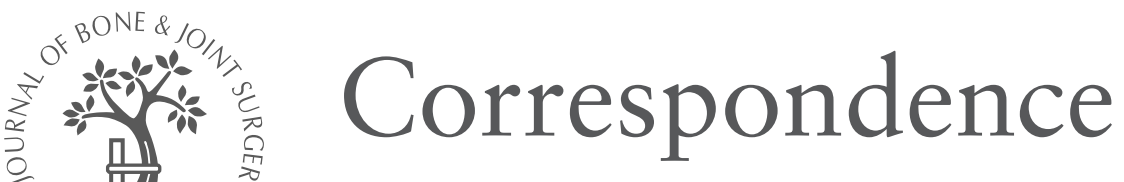

We welcome letters to the Editor concerning articles which have recently been published. Such letters will be subject to the usual stages of selection and editing; where appropriate the authors of the original article will be offered the opportunity to reply.

Letters should normally be under $\mathbf{3 0 0}$ words in length, doublespaced throughout, signed by all authors and fully referenced. The edited version will be returned for approval before publication.

(C)2004 British Editorial Society of Bone and Joint Surgery

doi:10.1302/0301-620X.86B2.15206 \$2.00

J Bone Joint Surg [Br] 2004;86-B:308-10.

\section{Outcome after reconstruction of the anterior cruciate ligament in athletic patients}

Sir,

We read with interest the article in the May 2003 issue by Meighan et $\mathrm{al}^{1}$ entitled 'Outcome after reconstruction of the anterior cruciate ligament in athletic patients'. We appreciated the effective study design and the simple and easy exposition. However, there was no mention of sample size or the statistical power.

It is disappointing that a valid paper is invalidated by the absence of this fundamental information. It is well known ${ }^{2,3}$ that sample size is important to establish the number of people for inclusion in a study in order to provide valid results. The statistical power gives information about the validity of significant results. If the sample is small, the results can be non-significant for this reason.

\author{
R. PADUA, MD \\ R. BONDI \\ E. CECCARELLI \\ San Giacomo Hospital \\ Rome, Italy.
}

1. Meighan AAS, Keating JF, Will E. Outcome after reconstruction of the anterior cruciate ligament in athletic patients. J Bone Joint Surg [Br] 2003;85-B:521-4.

2. Freedman KB, Back S, Bernstein J. Sample size and statistical power of randomised, controlled trials in orthopaedics. J Bone Joint Surg [Br] 2001:83-B:397-402.

3. Pijnenburg ACM, Bogaard K, Krips R, et al. Operative and functional treatment of rupture of the lateral ligament of the ankle. J Bone Joint Surg [Br]2003:85-B:525-30.

\section{Author's reply:}

Sir,

I would accept the criticism made by Dr Padua and his colleagues regarding our article. The sample size was small both in the early and late groups. The difficulties of recruiting patients to this type of surgery were referred to in our discussion. Although a larger sample size in both groups would have been desirable, we were unable to demonstrate any significant advantage for an immediate anterior cruciate ligament (ACL) reconstruction. In fact, the significant differences observed were in favour of delaying the procedure.
We consider that our study does contribute to the debate on this issue as there is an increasing tendency in some parts of the world to carry out immediate ACL reconstruction, without any evidencebased support that this is a more effective method of management.

\section{J. F. KEATING, FRCS Ed (Orth) \\ Royal Infirmary of Edinburgh \\ Edinburgh, Scotland.}

\section{Fixation of fractures of the femoral neck}

\section{Sir,}

We read with interest the paper by Lykke et al ${ }^{1}$ in the April 2003 issue entitled 'Fixation of fractures of the femoral neck: a prospective, randomised trial of three Ullevaal hip screws versus two Hansson hook-pins'.

The authors compare two different devices for internal fixation of femoral neck fractures. The study is based on radiographic outcome as well as the need for a secondary arthroplasty. One conclusion is that "osteosynthesis is the method of choice for most displaced fractures of the femoral neck". We don't find any support for this statement, in this study or in the literature. Furthermore, if followed by the readers, it may lead to tragic consequences for a large number of patients.

Firstly, 24 of $224(11 \%)$ displaced fractures in the study were regarded as 'irreducible' and excluded prior to randomisation. If these fractures, prone to healing complications, had been included, the failure rate after internal fixation of displaced femoral neck fractures would have been higher than the 70 of 200 $(35 \%)$ reported in the study. The results are in the range seen in other studies. $^{2}$

However, our main point is that the re-operation rate after internal fixation is not a suitable single outcome measure as it incorporates other factors such as local traditions and a willingness by the surgeon to re-operate. ${ }^{3}$

Six swedish prospective, randomised studies have compared internal fixation and primary arthroplasty in the treatment of displaced femoral neck fractures in the elderly. ${ }^{4-9}$ The general conclusion is that a primary cemented arthroplasty is superior to internal fixation regarding need for secondary surgery, function, pain, nutritional status and quality of life in the active and lucid patients without being more costly. ${ }^{4-13}$

\section{T. JOHANSSON, MD, PhD}

Linköping University Hospital, Sweden.

G. NEANDER, MD, PhD

Danderyds Hospital, Karolinska Institutet, Stockholm, Sweden.

C. ROGMARK, MD, PhD

Malmö University Hospital, Sweden. 
1. Lykke N, Lerud PJ, Stromsoe K, Thorngren KG. Fixation of fractures of the femoral neck: a prospective, randomised trial of three Ullevaal hip screws versus two Hansson hook-pins. J Bone Joint Surg [Br] 2003;85-B:426-30.

2. Lu-Yao G. Keller RB, Littenberg B, Wennberg JE. Outcomes after displaced fractures of the femoral neck: a meta-analysis of one hundred and six published reports. J Bone Joint Surg [Am] 1994;76-A:15-25

3. Alho A, Austdal S, Benterud JG, et al. Biases in a randomized comparison of three types of screw fixation in displaced femoral neck fractures. Acta Orthop Scand 1998;69:463-8.

4. Jonsson B, Sernbo I, Carlsson A, Fredin H, Johnell O. Social function after cervical hip fracture: a comparison of hook-pins and total hip replacement in 47 patients. Acta Orthop Scand 1996;67:431-4.

5. Neander G. Displaced femoral neck fractures: studies on osteosyntesis and total hip arthroplasty. Thesis 2000; Karolinks Institutet. http://diss.kib.ki.se/2000/91-6284167-X.

6. Johansson T, Jacobsson SA. Ivarsson I, Knutsson A, Wahlstrom O. Internal fixation versus total hip arthroplasty in the treatment of displaced femoral neck fractures: a prospective randomized study of 100 hips. Acta Orthop Scand 2000;71:597-602

7. Rogmark C, Carlsson A, Johnell 0, Sernbo I. A prospective randomised trial of internal fixation versus arthroplasty for displaced fractures of the neck of the femur: functiona outcome for 450 patients at two years. J Bone Joint Surg [Br]2002;84-B:183-8

8. Tidermark J, Ponzer S, Svensson 0, Soderqvist A, Tornkvist H. Internal fixation compared with total hip replacement for displaced femoral neck fractures in the elderly: a randomised, controlled trial. J Bone Joint Surg [Br] 2003;85-B:380-8.

9. Roden M, Schon M, Fredin H. Treatment of displaced femoral neck fractures: a randomized minimum 5-year follow-up study of screws and bipolar hemiprostheses in 100 patients. Acta Orthop Scand 2003;74:42-4.

10. Bachrach-Lindström M, Johansson T, Unossom M, Ek AC, Wahlström 0. Nutritional status and functional capacity after femoral neck fractures: a prospective randomized one-year follow-up study. Aging 2000;12:366-74

11. Tidermark J, Zethraeus N, Svensson O, Tornkvist H, Ponzer S. Quality of life related to fracture displacement among elderly patients with femoral neck fractures treated with internal fixation. J Orthop Trauma 2002;16:34-8.

12. Johansson T, Bachrach-Lindström M, Aspenberg P, Jonsson D, Wahlström 0 The costs of a displaced femoral neck fracture: a randomized study between internal fixation and total hip arthroplasty. Manuscript.

13. Rogmark C, Carlsson A, Johnell 0, Serbo I. Cost analysis of internal fixation versus arthroplasty after displaced femoral neck fractures: a randomised study. Acta Orthop Scand 2003: in press.

Authors' reply:

Sir,

We thank Drs Johansson, Neander and Rogmark who all have published important randomised studies between osteosynthesis and arthroplasty for femoral neck fractures, for their comments.

We chose not to include the irreducible fractures. Inserting screws or pins into a fracture which is not reduced predisposes to complications of healing, as our study shows. In this setting, choosing an 'intention-to-treat' - analysis, or classifying these fractures as failures, would, in our opinion, be wrong.

Johansson et al seem to have misunderstood the message in our study, thinking that all displaced femoral neck fractures should be internally fixed according to our recommendations. We are well aware of the randomised studies they referred to and the present trend in Sweden to perform more primary arthroplasties for the displaced femoral neck fractures. The important message from our study is that a certain number of these fractures benefit from primary internal fixation and that better results are achieved if the operations are performed according to criteria of accurate reduction and positioning of internal fixation. Therefore, we found it important to report results from Norway, where the quality and the number of cases of internal fixation is still high.

All our patients were called in for radiographic and clinical evaluation at four months, one year and two years after the operation. The outcome is thus based not only on 'need for reoperation', but also on repeated radiographic evaluation, evaluation of functional outcome, assessment of pain, as well as a description of the living conditions of the patients.
An observation not previously reported is that the penetration of the drill into the joint during surgery changes the fate of the fracture dramatically. This observation is to our knowledge new. It is also a warning against relief of pressure by intentionally drilling up into the joint to evacuate bleeding tamponade. High intracapsular pressures have been registered in undisplaced fractures of the femoral neck. ${ }^{1}$ Aspiration of the haemorrhage is recommended in these cases.

Arthroplasty in all cases of displaced femoral neck fractures can be considered as unnecessary overtreatment. An optimised balance between primary internal fixation and primary arthroplasty is the goal for future treatment. At the present stage we recommend: do not behead all because some fail.

N. LYKKE

P. J. LERUD

K. STRØMSØE

Aker University Hospital,

Oslo, Norway.

\section{K-G THORNGREN}

Lund University Hospital, Lund, Sweden.

1. Strömqvist B, Nilsson LT, Egund N, Thorngren KG, Wingstrand H. Intracapsular pressures in undisplaced fractures of the femoral neck. J Bone Joint Surg $[\mathrm{Br}]$ 1988:70-B:192-3.

\section{A strategy for reducing blood-transfusion requirements in elective orthopaedic surgery}

Sir,

We read with interest the article by Jeserschek et $\mathrm{al}^{1}$ in the March 2003 issue entitled 'Reduction of blood loss using high-dose aprotinin in major orthopaedic surgery' and by Helm et $\mathrm{al}^{2}$ in the May 2003 issue entitled 'A strategy for reducing blood-transfusion requirements in elective orthopaedic surgery'.

The reduction of perioperative blood loss, and more appropriate use of allogenic blood products must be a clinical priority. ${ }^{3-7}$ These two articles ${ }^{1,2}$ provide only part solutions to improving current practice. Their practical impact is limited by their own perspective.

The ideal solution includes 'core' (applicable to all Trusts) and 'optional' (adopted according to local preference and resource availability) elements.

Pre-operative: (optional elements in italics)

- Early pre-assessment, ${ }^{8}$ identifying/treating those patients with low $\mathrm{Hb}(<11 \mathrm{~g} / \mathrm{dl})^{9}$

- Homologous transfusion/pre-donation ${ }^{10}$

Peri/Intra-operative:

- Normovolaemic haemodilution ${ }^{11}$

- Anti-fibrinolytic therapy ${ }^{12,13}$

- Anaesthetic technique

- Cell salvage ${ }^{14}$

Post-operative

- Agreed transfusion triggers and blood prescribing practice ${ }^{15}$

- Cell salvage

- 'Near Patient' Hb/Hct monitoring

- Iron supplementation, and $\mathrm{Hb}$ follow-up in the community 
A combination stategy with co-ordinated pre-, peri- and postoperative elements is far more likely to achieve maximum practical impact. Both articles addressed different aspects of the same problem, but failed to develop this into a co-ordinated solution based on the whole patient process. One of the incentives for the Helm article was the restrictive cost of cell salvage. However, they failed to consider the potential value/role of anti-fibrinolytic therapy as a cheaper alternative. Jeserschek et $\mathrm{al}^{1}$ used aprotinin; other drugs have been used successfully in this context, ${ }^{12,13}$ are cheaper and have reduced allergic side effects.

Pivotal to any pragmatic improvement in current practice is the need for re-education and the development of a consensus approach. To be achievable and to realise the full potential of any change, close cross speciality co-operation (surgeons, anaesthetists and GPs) is vital. With appropriate dialogue, the role of each clinician can be defined and protocols drawn up and adapted according to local factors.

\section{BOOTH}

E. KOTHMANN

M. TIDMARSH

Cumberland Infirmary,

Carlisle, Cumbria.

1. Jesercheck R, Clar H, Aigner C, et al. Reduction of blood loss using high-dose aprotinin in major orthopaedic surgery: a prospective, double-blind, randomised and placebo controlled study. J Bone Joint Surg [Br] 2003; 85-B:174-7.

2. Helm AT, Karski MT, Parsons SJ, Sampath JS, Bale RS. A strategy for reducing blood-transfusion requirements in elective orthopaedic surgery: audit of an algorithm for arthroplasty of the lower limb. J Bone Joint Surg [Br] 2003;85-B:4849.

3. Goodnough LT, Brecher ME, Kanter MH, Auberchon JP. Transfusion medicine: blood transfusion. N Engl J Med 1999;340:438-47.

4. Turner M. The impact of new-variant Creutzfeldt-Jakob disease on blood transfusion practice. Br J Haemato/ 1999;106:842-50.

5. Anderson KC, Goodnough LT, Sayers M, et al. Variation in blood component practice implications for prevention of transfusion-associated graft versus host disease. Blood 1991;77:2096-102.

6. British Blood Transfusion Society web-page (www.bbts.org.uk).

7. Guidelines for the blood transfusion services in the United Kingdom. 6th edition. Published by TSO

8. Department of Health NHS Modernisation Agency. National Good Practice Guidance on pre-operative assessment for inpatient surgery. Complementary supplement March 2003.
9. Salido JA, Martin LA, Gomez LA, Zorilla P, Martinez C. Preoperative haemoglobin levels and the need for transfusion after prosthetic hip and knee surgery: analysis of predictive factors. J Bone Joint Surg [Am] 2002;84-A:216-20.

10. British Committee for Standards in Haematology (BCSH). Guidelines for autologous transfusion I. Pre-operative autologous donation. Transfusion Medicine 1993;3:307-16

11. Robertie PG, Gravlee GP. Safe limits of isovolemic haemodilution and recommendations for erythrocyte transfusion. Int Anaesthesiol Clin 1990;28:197-204.

12. Veien M, Sørensen JV, Madsen F, Juelsgaard P. Tranexamic acid giving intraoperatively reduces blood loss after total knee replacement: a randomised, controlled study. Acta Anaesthesiologica Scand 2002;46:1206-11.

13. Hiippala S, Strid L, Wennerstrand $\mathbf{M}$, et al. Tranexamic acid (Cyclokapron) reduces perioperative blood loss associated with total knee arthroplasty. B J Anaesthesia 1995; $74: 534-7$

14. British Committee for Standards in Haaematology (BCSH). Guidelines for preoperative autologous transfusion II. Perioperative haemodilution and cell salvage. Br J Anaesthesia 1997:78:768-71.

15. The Handbook of Transfusion Medicine. 3rd Edition. Published by the Blood Transfusion Services of the United Kingdom. Edited by DBL McClelland.

\section{Author's reply:}

Sir,

May I thank the authors for their interest in our paper. The preoperative, peri/intra-operative and post-operative factors listed in their letter are a useful summary of the various modalities which one can employ to limit the transfusion of allogenic blood. Our protocol was devised according to the facilities available to us at the time. Although our protocol clearly does work, I do not suggest that it is perfect in every respect. However, as stated in our discussion, I would advocate that many of the principles of our protocol, such as the introduction of rigid guidelines, education of medical and nursing staff, use of clinical audit, bedside haematocrit estimation and a more scientific approach to the problem are important factors in reducing transfusion of allogenic blood. We did not consider anti-fibrinolytic therapy as part of our protocol, and I hope the authors would agree that if we were to use this as well as our protocol, the number of units of allogenic blood transfused could be further reduced.

\section{A. T. HELM, MRCS}

Royal Preston Hospital,

Preston, UK. 